Jemilohun et al., Afr. J. Infect. Dis. (2014) 8(2): 40 - 43

http://dx.doi.org/10.4314/ajid.v8i2.5

\title{
PREVALENCE OF HEPATITIS C VIRUS ANTIBODY AMONG UNDERGRADUATES IN OGBOMOSO, SOUTH- WESTERN NIGERIA
}

\author{
Abiodun Christopher Jemilohun ${ }^{1}$, Bolaji Oyetunde Oyelade ${ }^{2}$, Sebastine Oseghae Oiwoh ${ }^{3}$
}

\author{
${ }^{1}$ Department of Medicine, Gastroenterology Unit, Ladoke Akintola University of Technology Teaching Hospital, P.M.B. \\ 4007, Ogbomoso , Oyo State, Nigeria. ${ }^{2}$ Ladoke Akintola University of Technology Health Center, Ogbomoso, Oyo State, \\ Nigeria. ${ }^{3}$ Department of Medicine, Ladoke Akintola University of Technology Teaching Hospital, Ogbomoso, Oyo State, \\ Nigeria. \\ Email: chrislohun2010@ hotmail.com
}

\begin{abstract}
Background: This study was conducted to determine the prevalence of hepatitis C virus antibody (anti-HCV), among a healthy university undergraduate population in south-western Nigeria.

Materials and Methods: Relevant medical information of students who underwent the post-admission screening exercise for the year 2012, at the Ladoke Akintola University of Technology (LAUTECH), Health Center, Ogbomoso were extracted from the laboratory log book. All tests were done using rapid anti-HCV test kit by Health - Chem diagnostics, USA. A total of 1,572 students were included in the study. The mean age was 19.61 ( \pm 2.75) years while the age range was 15- 50 years. A total of 821 (52.20\%), of the subjects were males while $751(47.80 \%)$ were females. More than ninety nine percent $(99.90 \%)$ of the subjects were aged $15-30$ years, whereas those aged $\geq 31$ years were comparatively few $(0.60 \%)$.

Results: Of the 1572 students, 6 tested positive, giving an overall prevalence of $0.40 \%$. Three $(0.37 \%)$ of the 821 male subjects tested positive while $3(0.40 \%)$ also of the 751 female subjects tested positive. Age-group 21-30 years had the highest prevalence of anti - HCV $(0.50 \%)$, followed by agegroups $\leq 20$ years with $0.30 \%$ prevalence. None of the subjects in age-groups $31-40$ and $\geq 41$ years tested positive.

Conclusion: These observed differences were not statistically significant. The prevalence of Hepatitis C Virus is low among the young healthy undergraduate population in the south - western region of Nigeria.
\end{abstract}

Key words: Hepatitis C Virus, Antibody, Prevalence, Infection, Nigeria.

\section{Introduction}

Hepatitis C virus is a spherical, enveloped single stranded hepatotropic RNA virus that belongs to the flaviviridae family (Sharma, 2010). It was first established in 1975, that the majority of the observed transfusion-associated hepatitis cases were caused by neither hepatitis A virus nor hepatitis B virus (the only two known human hepatitis viruses at that time). The new disease was therefore called non-A non-B hepatitis (NANBH), and the presumed etiological agent was called non-A non-B hepatitis virus (WHO, 2002). Hepatitis C virus was later identified in 1989, as the agent responsible for most of the transfusion-associated NANBH (WHO, 2002; Choo et al., 1989).

Hepatitis $\mathrm{C}$ virus (HCV) causes both acute and chronic forms of hepatitis. After the initial infection, approximately $80 \%$ of people do not exhibit any symptom (WHO, 2000). About 75-85 \% of newly infected individuals will progress to chronic disease (WHO, 2000; Seeff, 1999). Around $20 \%$ of infected individuals will develop fibrosis and cirrhosis; of these, approximately $20 \%$ will progress to hepatocellular carcinoma (HCC), (Seeff, 1999). In $25 \%$ of all liver cancer patients, the underlying cause is HCV (WHO, 2000).

The most common mode of Hepatitis $\mathrm{C}$ virus transmission is through exposure to infectious blood which usually occur through receipt of contaminated blood, blood products transfusions and organ transplants; injections given with contaminated syringes and needles, needle-stick injuries in health-care settings, intravenous injection drug of abuse; and being born to a hepatitis C virus infected mother (Lavanchy and Gavinio, 2000; Lavanchy, 1999). To a lesser extent, the virus may be transmitted through sexual intercourse with an infected person or by sharing of bloodcontaminated personal items (WHO, 2000).

Hepatitis $\mathrm{C}$ virus infection is a major global health problem. It occurs among people of all ages, genders, races and world regions. Although, representative prevalence data do not exist in many countries, available data indicate that approximately $3 \%$, of the world's population is infected with HCV (WHO, 1999). It is estimated that about 3-4 million people are infected with HCV globally per annum. 150 million people are chronically infected, and more than 350,000 people die every year from hepatitis C-related liver diseases (WHO, 2000). Hepatitis C virus has been identified as the most common cause of post-transfusion hepatitis worldwide, accounting for approximately $90 \%$ of this disease in Japan, the United States and Western Europe (Lavanchy and Gavinio, 2000). Epidemiological data from different regions of the world show a wide variation in the prevalence pattern of HCV. The United Kingdom and the Scandinavia have the lowest prevalence (Wasley and Alter, 2000) while the highest prevalence has been reported from the African and Mediterranean regions (Shepard et al., 2005). Although no study has been conducted in Nigeria to determine the national prevalence of the disease, studies conducted in various population subgroups like blood donors, sickle cell anaemic patients, human immunodeficiency virus (HIV) infected patients, pregnant women, diabetic patients etc, showed divers prevalence rates ranging from $0.4 \%$ - $14 \%$ (Imoru et al., 2003; Udeze et al., 2009; Ogunro et al., 2007; Ndako et al., 2009; Nwannadi et al. 2012; Jeremiah et al. 2008; Udeze et al. 2011; Halim and Ajayi, 2000).

This study was conducted to determine the prevalence rate of anti-HCV among undergraduate students of the Ladoke Akintola University of Technology, Ogbomoso, among an essentially healthy young adult population who constitutes the reservior of voluntary blood donors in our society. It is our hope that the data genarated will be an addition to the existing pool of HCV data available in the country. 


\section{Materials and Methods \\ Study population}

Subjects consisted of students of the Ladoke Akintola University of Technology (LAUTECH), Ogbomoso who underwent routine postadmission medical screening in 2012. The LAUTECH, Ogbomoso student population consists majorly of male and female young adults from the south-western geopolitical zone of Nigeria and a minority from other regions of the country. A total number of 4,788 students were admitted in the year 2012, according to the admission office of the institution, but only 1,596 , students test results were found in the source document used for the study. Of this, 1,572, results were useable. The remaining 24 were not useable because their demographic information was incomplete.

\section{Data collection}

Relevant medical information of students was extracted from the laboratory log book. Demographic information (age and gender), and antiHCV status (positive or negative), of students were copied into a data sheet with columns for each of age, gender and anti-HCV status. Personal identification information of students such as names and admission numbers were excluded to ensure anonymity.

\section{Sample processing}

All tests were conducted at the LAUTECH Health Center laboratory by laboratory technologists using rapid anti-HCV test kits manufactured by Health-Chem diagnostics, USA. We received assurances from the Health Center's laboratory personnel that none of the results was brought from outside. Rapid anti-HCV test kit is a colloidal gold enhanced rapid immuno-chromatographic assay for qualitative detection of antibodies to HCV in human serum or plasma. The kit has a sensitivity and specificity of $100 \%$ and $97-99 \%$ respectively. The procedure was performed in compliance with the manufacturer's instructions.

\section{Statistical analysis}

An analysis of data was done by SPSS 16 (SPSS Inc. Chicago, Illinois, USA). Proportional differences were evaluated by chi-square test, using contingency tables. P value was considered significant if $\leq 0.05$.

\section{Results}

A total of 1,572 students were included in the study. The mean age was $19.61( \pm 2.75)$ years while the age range was $15-50$ years. Eight hundred and twenty-one (52.20\%) of the subjects were males whereas $751(47.80 \%)$ were females. More than ninety nine percent (99.90\%) of the subjects were aged $15-30$ years, while those aged $\geq 31$ years were comparatively few $(0.60 \%)$ (Table1).

Table 1: Age and Gender distribution of subjects

\begin{tabular}{lccc}
\hline Age & $\begin{array}{l}\text { Gender } \\
\text { Male (\%) }\end{array}$ & Female (\%) & Total (\%) \\
\hline $15-20$ & $549(34.90)$ & $615(39.00)$ & $1164(74.00)$ \\
$21-30$ & $262(16.70)$ & $136(8.70)$ & $398(25.30)$ \\
$31-40$ & $5(0.30)$ & $0(0)$ & $5(0.30)$ \\
$41-50$ & $5(0.30)$ & $0(0)$ & $5(0.30)$ \\
Total & & & $1572(100)$ \\
& $821(52.20)$ & $751(47.80)$ & \\
\hline
\end{tabular}

Mean $=19.61, \mathrm{SD}= \pm 2.75$

Of the 1,572 students, 6 tested positive, implying an overall prevalence of $0.40 \%$. Three $(0.37 \%)$ of the 821 male subjects tested positive while 3 $(0.40 \%)$ of the 751 female subjects tested positive (Table 2$)$. This gender related prevalence was not statistically significant $(p=1.00)$.

Table 2: Gender related Prevalence of HCV

\begin{tabular}{lrrr}
\hline Gender & $\begin{array}{l}\text { HCV status } \\
\text { Positive (\%) }\end{array}$ & Negative (\%) & \multicolumn{1}{c}{ Total (\%) } \\
\hline Male & $3(0.37)$ & $818(99.63)$ & $821(100)$ \\
& & & \\
\hline
\end{tabular}


Jemilohun et al., Afr. J. Infect. Dis. (2014) 8(2): 40 - 43 http://dx.doi.org/10.4314/ajid.v8i2.5

\begin{tabular}{lccc}
\hline Female & $3(0.40)$ & $748(99.60)$ & $751(100)$ \\
Total & $6(0.40)$ & $1566(99.60)$ & $1,572(100)$ \\
\hline
\end{tabular}

$\mathrm{X}^{2}=0.012 ; \mathrm{df}=1 ; \mathrm{p}=1.00$

The age related prevalence of the subjects is depicted in Table 3. Age groups 21-30 years had the highest prevalence of anti-HCV (0.50\%), followed by age-groups $\leq 20$ years with $0.30 \%$ prevalence. None of the subjects in age groups $31-40$ and $\geq 41$ years tested positive. These observed differences were not statistically significant.

Table 3: Age related Prevalence of HCV

\begin{tabular}{llll}
\hline Age & $\begin{array}{l}\text { HCV status } \\
\text { Positive (\%) }\end{array}$ & Total \\
\hline$\leq 20$ & $4(0.30)$ & $1160(99.70)$ & $1164(100)$ \\
$21-30$ & $2(0.50)$ & $396(99.50)$ & $398(100)$ \\
$31-40$ & $0(0)$ & $5(100)$ & $5(100)$ \\
$\geq 41$ & $0(0)$ & $5(100)$ & $5(100)$ \\
Total & $77(4.90)$ & $1495(95.10)$ & $1572(100)$ \\
& & &
\end{tabular}

\section{Discussion}

The prevalence rate of $0.40 \%$ obtained from this study is less than the World Health Organization global prevalence rate of $3 \%$ (WHO, 1999). Previous studies in different population subgroups in Nigeria, some African and Middle - Eastern countries have recorded varying prevalence rates of HCV (Jeremiah et al., 2008). Just like the prevalence of $0.40 \%$ obtained in this study, low HCV prevalence rates were recorded in some studies conducted among blood donors in Kano, Nigeria (0.40\%), Namibia (0.90\%), Sudan $(1.90 \%)$, Senegal $(0.80 \%)$, and Ghana (0.90\%), (Jeremiah et al., 2008; Imoru et al., 2003). However, higher prevalence rates were found in studies previously conducted in Nigeria; 4.50\%, among sickle cell disease patients with regular blood transfusion in Benin, 5.70\%, among HIV patients in Jos, $8 \%$, among university undergraduates in Ilorin, 5\%, and 12.30\%, in Port-Harcourt and Benin respectively (Nwannadi et al., 2012; Udeze et al., 2011; Inyama et al., 2005). High prevalence rates have also been found in different parts of Africa and the Middle - East. For instance prevalence rates of 5.20\%, 5.70\%, 19.20\% were reported among blood donors in Ghana, Saudi Arabia and Egypt respectively (Jeremiah et al., 2008; Acquaye and Tettey-Donkor, 2000). These prevalence rates disparities could result from different reasons. First, it could be a true reflection of the worldwide regional variation in the prevalence of HCV as a result of the prevailing unwholesome health practices in such regions (Wasley and Alter, 2000) or because of the high risk of exposure in the particular population subgroup studied e.g. Sickle cell disease patients, HIV/AIDS patients, commercial blood donors etc. Second, it could be as a result of the disparities in the diagnostic techniques and accuracies of the different assays used in conducting the studies. Third, it could be a reflection of birth cohort-effect on disease prevalence i.e. it may be a reflection of the impact of the recent general improvement in health practices on disease prevalence (Wasley and Alter, 2000), as majority of the subjects in our study were below the age of 30 years.

It was observed from our study that age-groups $21-30$ years had the highest prevalence of anti-HCV $(0.50 \%)$, followed by age groups $\leq 20$ years with $0.30 \%$ prevalence and none of the subjects aged 31 years and above tested positive. This observed disparity may not be the true reflection of the prevalence of $\mathrm{HCV}$ in the different age groups in the general populace since comparatively few subjects of older age groups were involved in the study (Table 3 ).

Our study showed a slightly higher prevalence among the female gender $(0.40 \%)$ than the male gender $(0.37 \%)$, although this is not statistically significant. This is similar to previous studies conducted in Ilorin, Jos and the Niger delta of Nigeria which all had a higher preponderance of HCV among the female participants (Udeze et al., 2011). This finding is however, contrary to a higher prevalence of HCV among male subjects in studies conducted in Ibadan, Nigeria, among blood donors and in Maiduguri, Nigeria, among AIDS' patients (Udeze et al., 2009; Udeze et al., 2011). It is difficult to adduce any particular reason to this slightly higher female preponderance because of the general low prevalence of the disease among the study population, more so, that the difference is not statistically significant.

It is our conclusion from this study that HCV prevalence is low among the young adult population of south-western Nigeria. This study provides additional data on the burden of the disease in Nigeria. Since majority ( $>80 \%)$ of those who contract HCV will progress to chronicity with attendant devastating consequences, it is our hope that a comprehensive survey of HCV prevalence will be conducted in Nigeria in no distant future to determine the national prevalence, regional prevalence differences, high risk groups, and the associated risk factors for contracting the disease. This will go a long way to help in articulating a deliberate national action plan to prevent the disease transmission and to treat those who are already infected. Such measures may include: public awareness campaign on how to reduce the risks of infection; formulation and strict implementation of 
safe national blood transfusion service policy; provision of voluntary counseling and test services, especially, for the at risk individuals like injection drug users, commercial sex workers and healthcare workers; provision of drugs and other related services at subsidized cost for management of those who test positive as the antiviral agents and the laboratory tests for patients' evaluation are often expensive.

\section{References}

1. Acquaye, J. K. and Tettey-Donkor, D. (2000). Frequency of hepatitis C virus antibodies and elevated serum alanine transaminase levels in Ghanaian blood donors. West Afr J Med, 19: 239-241.

2. Choo, Q. L., Kuo, G., Weiner, A. J., Overby, L. R., Bradley, D. W., and Houghton, M. (1989). Isolation of a cDNA clone derived from a blood-borne non-A, non-B viral hepatitis genome. Sci, 244: 359-362.

3. Halim, N. K., and Ajayi, O. I. (2000). Risk factors and seroprevalence hepatitis C antibody in blood donors in Nigeria. East Afri Med J., 77: $410-412$.

4. Imoru, M., Eke, C., and Adegoke, A. (2003). Prevalence of Hepatitis-B Surface Antigen (HbsAg), Hepatitis C Virus (HCV) and Human Immunodeficiency Virus (HIV) among Blood Donors in Kano State, Nigeria. J. Medical Laboratory Sci., 12: 59-63.

5. Inyama, P. U., Uneke, C. J., Anyanwu, G. I., Njoku, O. M., Idoko, J. H., and Idoko, J. A. (2005). Prevalence of antibodies to Hepatitis C virus among Nigerian patients with HIV infection. Online J Hlth Allied Scs, 2: 2.

6. Jeremiah, Z. A., Koate, B., Buseri, F., and Emelike, F. (2008). Prevalence of antibodies to hepatitis C virus in apparently healthy Port Harcourt blood donors and association with blood groups and other risk indicators. Bld Transfus, 6: 150-155.

7. Lavanchy, D. (1999). Hepatitis C: public health strategies. J Hepatol, 31 Suppl 1: 146-151.

8. Lavanchy, D., and Gavinio, P. (2000) Hepatitis C. Can J Gastroenterol, 14 Suppl B, 67B-76B.

9. Ndako, J. A., Echeonwu, G. O., Shidali, N. N., Bichi, I. A., Paul, G. A., Onovoh, E., and Okeke, L. A. (2009). Occurrence of Hepatitis C Virus infection in type 2 diabetic patients attending Plateau state specialist hospital Jos Nig Virology J, 6: 98

10. Nwannadi, I. A., Alao, O. O., Bazuaye, G. N., Omoti, C. E., and Halim, N. K. (2012). Seroprevalence of Hepatitis C Virus Antibody in Sickel Cell Anaemia patients in Benin-City, Nigeria. Gomal J of Med Sci, 10: 1.

11. Ogunro, P. S., Adekanle, D. A., Fadero, F. F., Ogungbamigbe, T. O., and Oninla, S. O. (2007). Prevalence of anti-hepatitis C virus antibodies in pregnant women and their offspring in a tertiary hospital in Southwestern Nigeria. J Infect Dev Ctries, 1: 333-336

12. Seeff, L. B. (1999). Natural history of hepatitis C. Am J Med, 107: 10S-15S.

13. Sharma, S. D. (2010). Hepatitis C virus: molecular biology \& current therapeutic options. Indian J Med Res, 131. 17-34

14. Shepard, C. W., Finelli, L., and Alter, M. J. (2005). Global epidemiology of hepatitis C virus infection. Lancet Infect Dis, 5, 558-567.

15. Udeze, A. O., Bamidele, R. A., Okonko, I. O., and Sule, W. F. (2011). Hepatitis C Virus (HCV) Antibody Detection Among First Year Students of University of Ilorin, Ilorin, Nigeria. World J of Med Sci. 6. 162-167.

16. Udeze, A. O., Okonko, I. O., Donbraye, E., Sule, W. F., Fadeyi, A. and Uche, L. N. (2009). Seroprevalence of Hepatitis C Virus Antibodies Amongst Blood Donors in Ibadan, Southwestern, Nigeria. World Appl Sci J., 7: 1023-1028.

17. Wasley, A. and Alter, M. J. (2000). Epidemiology of hepatitis C: geographic differences and temporal trends. Semin Liver Dis, 20. 1-16.

18. WHO (1999). Global surveillance and control of hepatitis C. Report of a WHO Consultation organized in collaboration with the Viral Hepatitis Prevention Board, Antwerp, Belgium. J Viral Hepat, 6. 35-47.

19. WHO. Hepatitis C Fact sheet N ${ }^{\circ} 164.2000$ [updated 2000 July 2012; cited]; Available from: http://www.who.int/mediacentre/factsheets/fs164/en/.

20. WHO (2002). Global Alert and Response: Hepatitis. C. 2002 [updated 2002; cited]; Available from: http://www.who.int/csr/disease/hepatitis/whocdscsrlyo2003/en/. 